\title{
EMPLOYMENT AND INCOME IN THE SUGARCANE AGRIBUSINESS IN THE BRAZILIAN STATE OF SÃO PAULO
}

\author{
Rodolfo Hoffmann and Fabiola Cristina Ribeiro de Oliveira
}

\section{INTRODUCTION}

This paper examines employment and income in sugarcane cultivation, and sugar and alcohol production from sugarcane, taken together as one industry or sector, i.e., the "sugarcane agribusiness", in the state of São Paulo, Brazil. The analysis uses statistical data on people employed in the sugarcane culture, the sugar and ethanol industry in Brazil. This chapter does not cover all employment generated by the expansion of the sector. One important aspect is, for instance, the production of agricultural machinery (in particular sugarcane harvesting machines), and equipment for sugar mills and the ethanol industry. While analyzing sugarcane agribusiness, as defined above, one should recall the multiplier effects associated to the changes taking place, both downstream and upstream considered in this industry.

\section{NUMBER OF PEOPLE EMPLOYED AND THEIR INCOME}

Data about quantity, earnings and other characteristics of the people occupied in sugarcane cultivation and the sugar and alcohol industrie, can be obtained from the National Household Sample Survey - PNAD, from the Annual Record of Social Information - RAIS prepared by the Brazilian Ministry of Labor and Employment and also from the Demographic Census. The information in PNAD and the Census is obtained from a questionnaire send out and the reply sent back by persons in the household sample; the Annual RAIS Record of the
Labor Ministry is a census of the formal employment market reported by the employers.

Using 2005 RAIS data, MORAES (2007a) observes that the number of employees were 415,000 in the sugarcane production, 440,000 in sugar mills and 128,000 in the alcohol industry, or a total of 983,000 in the sugarcane agribusiness of Brazil, as shown in Table 1.

Table 2 shows the number of people employed in the sector according to 2005 PNAD data. There are some discrepancies between data from PNAD and RAIS; and more research is needed to establish which of these sources better reflects the real situation. The mills often produce both sugar and alcohol, and thus the distinction between employment in these mills is somewhat arbitrary. However, even if we take the aggregate of the two industries, the difference between these two sources remains substantial.

According to RAIS (Table 1), 42\% of the employees in the sector as a whole in Brazil are occupied in sugarcane production, while according to PNAD (Table 2) this proportion is as high as $72 \%$. It could be that the reason for this difference is a much higher proportion of laborers in cultivation in the Northeastern region who are not formally registered and thus are not included in the RAIS data provided by the employers. There are also considerable differences between the two sources on average earnings, although the data always indicate average earnings lower in cultivation than in the industry.

According to the 2007 PNAD, the number of employees in the sugarcane agribusiness in 
TABLE 1 Number of employees and average monthly earnings in the sugar-alcohol sector in Brazil and the State of São Paulo, in 2005, cf. RAIS.

\begin{tabular}{|l|c|c|c|}
\hline \multicolumn{1}{|c|}{ Geographic unit } & Sector & N. of employees & Average earnings* \\
\hline Brazil & Sugarcane agribusiness & 982,604 & 675 \\
\hline Brazil & Surgarcane cultivation & 414,668 & 647 \\
\hline Brazil & Sugar industry & 439,573 & 691 \\
\hline Brazil & Ethanol industry & 128,363 & 706 \\
\hline São Paulo & Sugarcane agribusiness & 385,533 & 860 \\
\hline São Paulo & Sugarcane culture & 220,517 & 754 \\
\hline São Paulo & Sugar industry & 131,867 & 1,032 \\
\hline São Paulo & Ethanol industry & 33,149 & 887 \\
\hline
\end{tabular}

* Values in R\$ of 2005 .

Source: MORAES (2007a, p. 895).

TABLE 2 Number of employees and average earnings in all categories of workers in the sugarcane agribusiness, Brazil and in the State of São Paulo, in 2005, cf. PNAD.

\begin{tabular}{|l|c|c|c|}
\hline \multicolumn{1}{|c|}{ Geographic unit } & Sector & N. of occupied & Average earnings* $^{*}$ \\
\hline Brazil & Sugarcane agribusiness & 719,926 & 537 \\
\hline Brazil & Sugarcane culture & 519,561 & 729 \\
\hline Brazil & Sugar industry & 120,370 & 961 \\
\hline Brazil & Ethanol industry & 79,995 & 782 \\
\hline São Paulo & Sugarcane agribusiness & 251,674 & 643 \\
\hline São Paulo & Sugarcane culture & 153,926 & 837 \\
\hline São Paulo & Sugar industry & 52,781 & 1,196 \\
\hline São Paulo & Ethanol industry & 44,967 & 2 \\
\hline
\end{tabular}

* R\$ of September 2005.

Source: MICRODADOS from PNAD 2005.

the State of São Paulo reached 355,042, of which 194,923 correspond to sugarcane production, 82,347 in the sugar industry, and 77,772 in the ethanol industry. PNAD also registers occupied people who are not employees (employers and self-employed). The total number of people occupied in the sector in the State of São Paulo reached 360,532 in 2007, an increase of 22\% over 2006 and 41\% over 2005.

Even with such an expansion, occupation and employment in the sugarcane culture has suffered, and will continue to suffer, a strong impact from increased mechanization of the production process. Technological progress in the sugarcane production has been influenced essentially by two factors: i) restructuring of the agricultural production model, aiming at reducing costs and increasing productivity e.g. mechanized harvest can reduce costs by 30\% in comparison to the manual harvest (cf. OLIVEIRA, 2002); ii) institutional changes, such as a drastic reduction of governmental intervention in the sugar-alcohol sector, together with the gradual reduction of burning cane during harvest, as noted by MORAES (2007c). 
TABLE 3 Area mechanical harvested as \% of total area in sugarcane cultivation. Brazil, Center-South, Northeast and São Paulo, 1997-2002.

\begin{tabular}{|c|c|c|c|c|}
\hline Year & Brazil & Center-South & Northeast & São Paulo \\
\hline 1997 & 13.5 & 15.4 & 3.2 & 17.8 \\
\hline 1998 & 23.8 & 24.9 & 5.7 & 26.4 \\
\hline 1999 & 23.0 & 25.3 & 5.9 & 3.6 \\
\hline 2000 & 24.7 & 28.0 & 8.0 & 30.5 \\
\hline 2001 & 29.0 & 31.0 & 9.0 & 35.0 \\
\hline 2002 & 31.8 & 32.5 & & 35.0 \\
\hline
\end{tabular}

Source: Idea News (2002). Adapted from OLIVEIRA (2002, p.78).

Legislation $^{1}$, which aims at reducing environmental consequences and damage to public health, established that sugarcane burning in areas that can be mechanized has to be phased out by 2021, and in areas that can not be mechanized ${ }^{2}$ until no later than 2031. Moreover, according to the Agro-environmental Protocol signed with the state government in July 2007, sugarcane growers and the sugar and alcohol industry of the State of São Paulo have agreed to bring forward the deadline for the elimination of sugarcane burning from 2021 to 2014, in land with slopes up to $12 \%$. They are also committed to improve the proportion of sugarcane not burnt from 30\% to $70 \%$ of the total in 2010 in the State of São Paulo. In land with slopes above $12 \%$, the date will be brought forward from 2031 to 2017, improving from 10\% to $30 \%$ the proportion of sugarcane not burnt, in $2010^{3}$. As noted in BACCARIN et al. (2008), more than a governmental option, the signature of the Protocol seems to reflect the entrepreneurial decision to accelerate harvest mechanization. One reason is to obtain easier access to foreign markets for ethanol, in countries with strict environmental

\footnotetext{
1 Law of the State of São Paulo n. 11241 of 2002.

2 Areas with slope above $12 \%$ and rocky terrain. VEIGA FILHO et al. (1994) consider that this physical constraint represents almost half (44\% to 55\%) the area under sugarcane cultivation in the State of São Paulo.

3 See Protocolo Agro-ambiental SAA/SMA/Setor Sucroalcooleiro (Agro-environmental Protocol SAA/SMA/SugarAlcohol sector) at: <www.iea.sp.gov.br>.
}

laws, but changes in the labor market conditions, with the expansion of formal employment, are also inducing mechanization.

According to information obtained from OLIVEIRA (2002), mechanization is expanding rapidly, so much that between 1997 and 2002 the mechanically harvested area almost doubled in the State of São Paulo, going from 17.8\% in 1997 to $35 \%$ in 2002 (see Table 3).

Another way of estimating the number of people employed in the sugarcane culture is to use production data (or area harvested) together with technical coefficients. FREDO (2008) calculates that in the 2007/08 harvest, $40.7 \%$ of the area harvested in the State of São Paulo was by mechanical means; assuming 132 actual working days during harvest and an average of 8.76 tons of cane harvested manually per worker-day, "it was estimated that around 163,098 people were occupied in the sugarcane harvest".

HOFFMANN and OLIVEIRA (2008a) use PNAD data to analyze the evolution of real wages of employees in the sugarcane culture in Brazil, and in the State of São Paulo, for the period 1992 - 2006. From 2001 on, it is obvious that there is a strongly correlation of the wages received by these workers with the value of the legal minimum wage.

When comparing different crops, it is worthwhile to look at the results of the "Employment quality index" defined and calculated by BALSADI (2007a and 2008). This index (IQE, for "Índice de Qualidade do Emprego") shows a substantial 


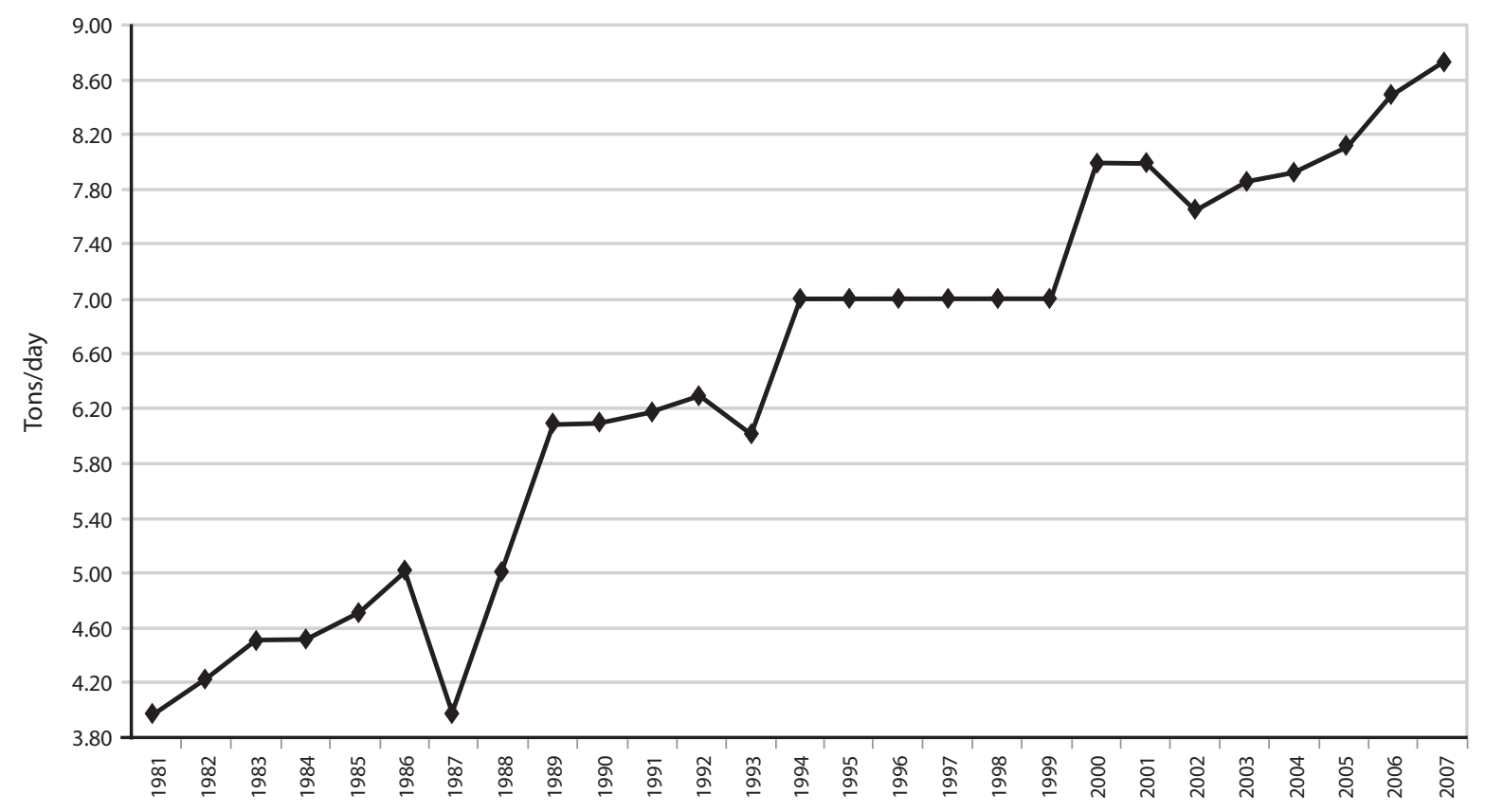

Source: IEA/CATI, Secretary of State for Agriculture, State of São Paulo.

FIGURE 1 Evolution of average labor productivity ${ }^{4}$ in the manual sugarcane harvest in São Paulo 1980-2007.

improvement in the quality of employment in the sugarcane culture. IQE for permanent urban workers goes from 51.5 in 1992 to 64.8 in 2004. For temporary urban worker the index goes from 38.2 to 51.6 in the same period. Crops analyzed by BALSADI (2008) includes rice, coffee, corn, manioc (cassava), sugarcane and soya - the last one presents the best indicators of employment quality, followed by sugarcane.

There isl another source of income data for people employed in sugarcane cultivation in the State of São Paulo, done by IEA/CATI, the Institute of Agricultural Economy to the Secretary of State for Agriculture of the State of São Paulo. Data are obtained from questionnaires that the technical staff running the Agriculture Houses supply regularly. Every year in June, data are thus collected on the physical yields and payment per ton of

4 That labor productivity, measured in tons/day, appears as relatively high in 2000 and 2001 is likely due to rounding of the values published by IEA. From 1994 to 2001 values are whole numbers, while from 2002 onwards the site of IEA (www.iea. sp.gov.br) publishes figures with decimals. sugarcane harvested. Changes that took place in the sugarcane culture went beyond the advance of mechanization, with the increase in average yields, including also increase in productivity of the sugarcane manual cutter. According to the IEA data, daily productivity of work in the sugarcane harvest, measured in tons cut per working day, shows a growing trend in the last decades. Average productivity per working day was 4 tons/day in 1980, and more than doubled, reaching almost 9 tons in 2007 (see Figure 1) ${ }^{5}$.

Up to 1992 there was a declining trend in the average amount paid per ton cane cut in the state of São Paulo. During the 1980s, values paid for harvested ton of sugarcane fluctuated considerably. From 1995 onwards, this value oscillates around $\mathrm{R} \$ 3.30$ (see Figure 2). It should be noted that increased productivity in the sugarcane sector is not reflected in an improvement of the wages of laborer, unless the laborer ncreases his/her productivity e.g. by cutting more cane.

5 No study evaluating the relative importance of the various determinants of such a strong productivity increase is known yet. 




Source: IEA/CATI, Secretary of State for Agriculture of the State of São Paulo.

FIGURE 2 Evolution of average pay for harvested ton of sugarcane in São Paulo 1980-2007.

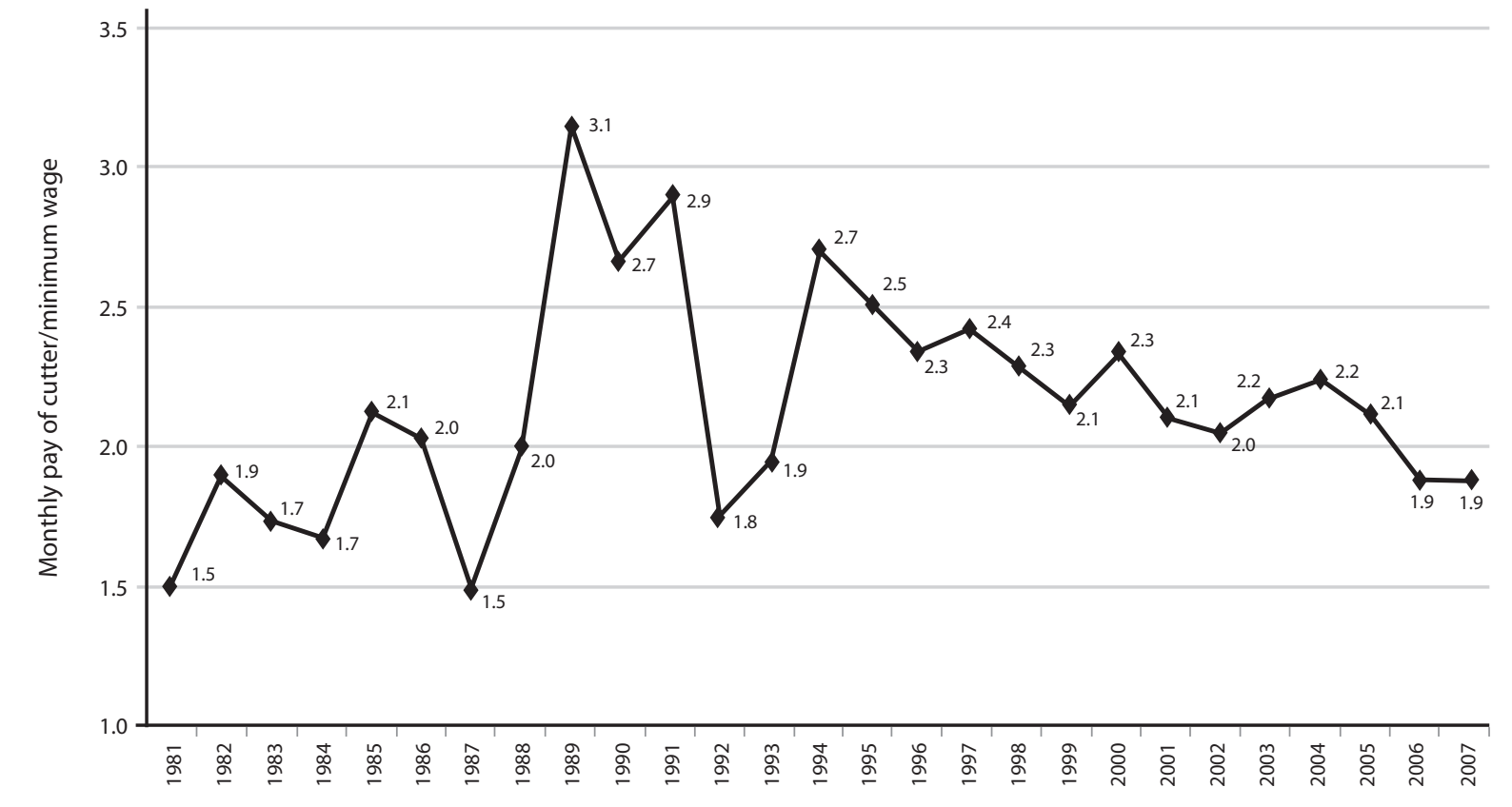

Source: IEA/CATI, Secretary of State for Agriculture of the State of São Paulo.

FIGURE 3 Evolution of the monthly earnings of sugarcane cutters measured in multiples of the current legal minimum wage in São Paulo 1980-2007. 
Assuming 25 working days per month, the real monthly earnings of sugarcane cutters did rise 47\% between 1994 and 2007, but such increase did not accompany the rise in the legal minimum wage. The ratio was more than 2 minimum wages between 1994 and 2005 and diminishes to 1.9 in 2006 and 2007 (see Figure 3). It should be noted, however, that the value of the minimum wage in June 2007, in real terms, is around twice what it was in June 1994.

OLIVEIRA (2009) analyzes the earnings obtained from harvesting coffee in the red cherry, coffee in the dried pod, oranges, lemons, tangerines and cotton, in the State of São Paulo, from 1995 to 2007, and then notes the rising trend in daily earnings from 2001, which is consistent with the rising trend in monthly earnings of the employees according to PNAD data. However, when comparing payment for contract work in harvesting various crops, she draws attention to the fact that remuneration in the sugarcane harvest is not the highest, but that of in coffee in the red cherry. It seems that the stronger physical effort needed for the cutting of cane does not bring higher remuneration. Apparently other characteristics are more relevant, such as longer duration of the harvest (less urgency in completing the task) and the low value of the product per unit of weight and volume.

There is not much economic research data on the determinants of wages of people employed in the sugarcane agribusiness, namely, studies where multiple regression is used to show how wages depend on the characteristics of the person employed (gender, age, schooling, skin color, personal connections, rural or urban residence) and characteristics of the employment (region, weekly hours worked, main activity of the establishment). HOFFMANN and OLIVEIRA (2008b), using PNAD 2006 data, have shown that after accounting for the effect of the remaining explanatory variables, the person employed in the sugarcane culture earns $23.2 \%$ less than the one employed in the ethanol industry. No significant difference exists between the ethanol industry and the sugar industry (Equation 1). An equation adjusted only to employees in the sugarcane culture reveals that temporary workers tend to earn 10\% less than permanent workers (Equation 2).
Adjusting an equation for all agricultural workers in Brazil, with data from PNAD 2007, we observe a relatively favorable position of wages earned in sugarcane culture. Taken account of the effect of the other variables of the model, the differential associated with employees' earnings in other crops examined in comparison to average earnings in sugarcane production are the following: $-9.9 \%$ in coffee, $-23.2 \%$ in manioc (cassava), $-30.1, \%$ in corn, $-0,2 \%$ in soya, $-30,1 \%$ in rice and $-12,5 \%$ in the remaining agricultural activities (Table 5). It is true that average wages in the soya culture are considerably higher than in sugarcane, but this is due to the difference in the level of average schooling, of 5.4 years in soya and only 4.2 years in sugarcane. While in the sugarcane culture $5.7 \%$ of the employees are tractor drivers, in the soya culture that proportion reaches $40.5 \%$.

Table 6 shows earnings equations estimated with aggregate data of the national sample survey PNAD from 1995 to 2007 (all earnings in Real $(\mathrm{R} \$$ ) of August 2008), applying as deflator the National Consumer Price Index INPC. From equations 4 and 5 it becomes clear that returns attributed to schooling increase considerably after 9 years have been completed. Over 9 years, each year of schooling determines a $2 \%$ increase in the earnings of the employee

Equation 4 shows that the coefficients of the binary variables that signal the crops other than sugarcane are all negative, showing that, after controlling for the effect of all other explanatory variables included in the regression, the employee in the sugarcane culture obtains a higher remuneration, particularly if compared to employees in the cultures of manioc, corn and rice.

As the data used correspond to 12 different years, the equations do capture the impact of the real minimum wage (RMW) on the earnings of the employees. It should be noted that the real minimum wage is measured in hundred Reais (RMW/100), to avoid that corresponding coefficient become too small that it is difficult to identify. According to equation 4 in Table 6, an increase of $\mathrm{R} \$ 100$ in the real minimum wage is associated with a $14.45 \%$ increase in the wages of permanent employees, formally registered and having some degree of specialization. The terms of interactions that include the RMW, indicate that changes in 
TABLE 4 Earnings equations for people employed in the sugarcane-based industry and in the sugarcane cultivation in Brazil 2006.

\begin{tabular}{|c|c|c|c|c|}
\hline \multirow{2}{*}{ Variable } & \multicolumn{2}{|c|}{$\begin{array}{c}\text { Equation } 1 \\
\text { Sugarcane-based Industry }\end{array}$} & \multicolumn{2}{|c|}{$\begin{array}{c}\text { Equation } 2 \\
\text { Sugarcane culture }\end{array}$} \\
\hline & Coefficient & $\%$ differ. & Coefficient & $\%$ differ. \\
\hline Constant & 3.0621 & - & 2.7828 & - \\
\hline Female & -0.2434 & -21.61 & -0.2440 & -21.65 \\
\hline \multicolumn{5}{|l|}{ Age } \\
\hline Age/10 & 0.3166 & - & 0.2995 & - \\
\hline$(\mathrm{Age} / 10)^{(2)}$ & -0.0324 & - & -0.0359 & - \\
\hline \multicolumn{5}{|l|}{ Schooling } \\
\hline Schooling $<=10$ years & 0.0245 & 2.48 & 0.0184 & 1.86 \\
\hline Schooling $>10$ years & 0.1851 & $23.32^{(1)}$ & 0.0980 & $12.35^{(1)}$ \\
\hline Log (hours worked in week) & 0.5892 & & 0.6313 & \\
\hline \multicolumn{5}{|l|}{ Color (Base: white) } \\
\hline Black or mixed & -0.0161 & $-1.60^{(2)}$ & 0.0401 & $4.09^{(2)}$ \\
\hline Yellow (Asiatic) & -0.0977 & $-9.30^{(2)}$ & -0.0428 & $-4.19^{(2)}$ \\
\hline Person of ref. in family & 0.1017 & 10.70 & 0.0146 & $1.47^{(2)}$ \\
\hline Rural Residence & -0.0538 & $-5.24^{(2)}$ & - & - \\
\hline \multicolumn{5}{|l|}{ Region (Base: NE) } \\
\hline North ${ }^{(3)}$ & -0.1474 & $-13.70^{(2)}$ & 0.0859 & $8.97^{(2)}$ \\
\hline Southeast (excl. SP) & 0.1205 & 12.80 & 0.1354 & 14.50 \\
\hline S. Paulo & 0.4640 & 59.05 & 0.5310 & 70.07 \\
\hline South & 0.2189 & 24.47 & 0.2532 & 28.82 \\
\hline Center-West & 0.2915 & 33.84 & 0.4082 & 50.41 \\
\hline \multicolumn{5}{|l|}{ Activity (Base: ethanol ind.) } \\
\hline Sugarcane culture & -0.2644 & -23.23 & - & - \\
\hline Sugar industry & -0.0265 & $-2.61^{(2)}$ & - & - \\
\hline Temporary employees & - & - & -0.1054 & -10.00 \\
\hline$R^{2}$ & \multicolumn{2}{|c|}{58.66} & \multicolumn{2}{|c|}{42.41} \\
\hline$F$ test $^{(4)}$ & \multicolumn{2}{|c|}{112.20} & \multicolumn{2}{|c|}{46.30} \\
\hline Number of observations & \multicolumn{2}{|c|}{1,362} & \multicolumn{2}{|c|}{959} \\
\hline
\end{tabular}

(1) This is the percentage growth in earnings associated with one additional year of schooling, over and beyond 9 years, as calculated, for instance, $100[\exp (0.0245+0.1851)-1] \%=23.32 \%$.

(2) The coefficients are not statistically different from zero at a significance level of $5 \%$.

(3) Excluding the rural area of Rondonia, Acre, Amazonas, Roraima, Pará and Amapá.

(4) The values of $F$ are statistically significant at $1 \%$.

Note: The dependent variable is the logarithm of the earnings from all work. 
TABLE 5 Earnings equation for agricultural workers in Brazil 2007.

\begin{tabular}{|c|c|c|}
\hline \multirow{2}{*}{ Variable } & \multicolumn{2}{|c|}{ Equation 3 - Agriculture } \\
\hline & Coefficient & $\%$ diff. \\
\hline Constant & 2.8703 & - \\
\hline Female employee & -0.1141 & -10.78 \\
\hline \multicolumn{3}{|l|}{ Age } \\
\hline Age/ 10 & 0.2143 & - \\
\hline$($ Age/ 10)(2) & -0.0242 & - \\
\hline \multicolumn{3}{|l|}{ Schooling } \\
\hline Schooling $<=9$ years & 0.0187 & 1.89 \\
\hline Schooling $>9$ years & 0.0704 & $9.31^{(1)}$ \\
\hline Log (hours worked in week) & 0.7245 & - \\
\hline \multicolumn{3}{|l|}{ Color (Base: white) } \\
\hline Black or mixed & -0.0250 & $-2.47^{(2)}$ \\
\hline Yellow (Asiatic) & 0.1400 & $15.03^{(2)}$ \\
\hline Person of reference in family & 0.0850 & 8.87 \\
\hline Rural residence & -0.0044 & $-0.44^{(2)}$ \\
\hline \multicolumn{3}{|l|}{ Region (Base: Northeast) } \\
\hline North ${ }^{(3)}$ & 0.1876 & 20.63 \\
\hline Southeast (excl. SP) & 0.3350 & 39.80 \\
\hline S. Paulo & 0.4314 & 53.94 \\
\hline South & 0.4011 & 49.34 \\
\hline Center-West & 0.4068 & 50.19 \\
\hline \multicolumn{3}{|l|}{ Agricultural crop (Base: sugarcane) } \\
\hline Coffee & -0.1047 & -9.94 \\
\hline Manioc (cassava) & -0.2639 & -23.20 \\
\hline Corn & -0.3688 & -30.84 \\
\hline Soya & 0.0023 & $0.23^{(2)}$ \\
\hline Rice & -0.3577 & -30.07 \\
\hline Other agriculture ${ }^{(4)}$ & -0.1332 & -12.47 \\
\hline Employee with no formal register & -0.3795 & -31.58 \\
\hline Temporary employee & -0.0923 & -8.82 \\
\hline Employee without specialization & -0.1504 & -13.97 \\
\hline$R^{2}$ & \multicolumn{2}{|c|}{57.54} \\
\hline$F$ test $^{(5)}$ & \multicolumn{2}{|c|}{266.53} \\
\hline Number of observations & \multicolumn{2}{|c|}{4,745} \\
\hline $\begin{array}{l}\text { This is the percentage growth associated with } \\
100[\exp (0.0187+0.0704)-1] \%=9.31 \% \text {. } \\
\text { The coefficients are statistically not different frc } \\
\text { Excluding the rural area of the states of Rondor } \\
\text { Other crops, except sugarcane. } \\
\text { The values of } F \text { are statistically significant at } 1 \%\end{array}$ & ached at least $9 y$ & \\
\hline
\end{tabular}


agricultural wages attributed to changes in the legal minimum wage, have a stronger impact on the formally registered employee than on the informal laborer, and on the permanent employee than on the temporary one; and on the unskilled worker than on the skilled.

Equation 5 of Table 6 shows that, when the effect of the other variables included in the equation is controlled, the employee not formally registered tends to earn $23.75 \%$ less than the one registered; the temporary employee receives $10.44 \%$ less that the permanent, while employees without specialization 19.61\% less than the skilled. This equation allows us, moreover, to verify that the legal minimum wage has a different impact on the earnings of the employees in the various agricultural activities. For the sugarcane employee (activity taken as the base), an increase of $\mathrm{R} \$ 100.00$ in the RMW is associated with a rise of $14.71 \%$ in expected earnings. The terms of the interaction that considers RMW show how its effect on wages of employees in different agricultural activities is differentiated. Except for soya, the impact of the legal minimum wage on the earnings in the sugarcane culture is stronger than in the other crops, perhaps due to the relative weight of the sugarcane crop in the country's economy, more inspection about the enforcement of labor laws, and more active trade unions.

Finally, it should be noted that employees in the sugarcane culture have a better remuneration when we analyze the information given by workers in the various stages of the productive cycle (from PNAD). However, when we analyze the daily pay in the contracts for the harvest in the state of São Paulo, according to data from the Institute of Agricultural Economy of the Secretary of State for Agriculture of the State of São Paulo, what is paid in the sugarcane harvest is lower than the pay in the citrus harvest (oranges, lemon and tangerine) and in the coffee harvest (in the red cherry and in the dried pod).

\section{DOES SUGARCANE AGRIBUSINESS CONTRIBUTE TO INCREASE INEQUALITY?}

The sugarcane culture is highly concentrated. HOFFMANN and SILVA (1986) analyze the con-

TABLE 6 Earnings equations for people employed in agriculture in Brazil cf. PNAD data 1995-2007.

\begin{tabular}{|c|c|c|c|c|}
\hline \multirow{2}{*}{ Variable } & \multicolumn{2}{|c|}{ Equation 4} & \multicolumn{2}{|c|}{ Equation 5} \\
\hline & Coefficient & $\%$ diff. & Coefficient & $\%$ diff. \\
\hline Constant & 2.4213 & - & 2.4004 & - \\
\hline Female employee & -0.1461 & -13.59 & -0.1439 & -13.41 \\
\hline \multicolumn{5}{|l|}{ Age } \\
\hline Age/ 10 & 0.2288 & - & 0.2282 & - \\
\hline$(\mathrm{Age} / 10)^{(2)}$ & -0.0267 & - & -0.0267 & - \\
\hline \multicolumn{5}{|l|}{ Schooling } \\
\hline Schooling $<=9$ years & 0.0206 & 2.08 & 0.0204 & 2.06 \\
\hline Schooling $>9$ years & 0.0929 & $12.01^{(1)}$ & 0.0937 & $12.08^{(1)}$ \\
\hline Log (hours worked per week) & 0.7192 & - & 0.7234 & - \\
\hline \multicolumn{5}{|l|}{ Skin color (Base: white) } \\
\hline Black or mixed & -0.0514 & -5.01 & -0.0507 & -4.94 \\
\hline Yellow (Asiatic) & 0.3300 & 39.10 & 0.3332 & 39.55 \\
\hline Person of reference in the family & 0.0809 & 8.43 & 0.0808 & 8.41 \\
\hline
\end{tabular}




\begin{tabular}{|c|c|c|c|c|}
\hline \multirow{2}{*}{ Variable } & \multicolumn{2}{|c|}{ Equation 4} & \multicolumn{2}{|c|}{ Equation 5} \\
\hline & Coefficient & $\%$ diff. & Coefficient & $\%$ diff. \\
\hline Rural domicile & -0.0450 & -4.40 & -0.0466 & -4.55 \\
\hline \multicolumn{5}{|l|}{ Region (Base: NE) } \\
\hline North ${ }^{(3)}$ & 0.2792 & 32.20 & 0.2776 & 31.99 \\
\hline Southeast (excl. SP) & 0.2494 & 28.33 & 0.2508 & 28.50 \\
\hline S. Paulo & 0.4245 & 52.89 & 0.4256 & 53.05 \\
\hline South & 0.2502 & 28.42 & 0.2506 & 28.49 \\
\hline Center-West & 0.3945 & 48.36 & 0.3940 & 48.29 \\
\hline \multicolumn{5}{|l|}{ Agricultural segment (Base: sugarcane) } \\
\hline Coffee & -0.0919 & -8.78 & -0.0187 & $-1.85^{(2)}$ \\
\hline Manioc (cassava) & -0.2494 & -22.08 & -0.0786 & $-7.56^{(2)}$ \\
\hline Corn & -0.3029 & -26.14 & -0.0308 & $-3.03^{(2)}$ \\
\hline Soya & -0.0651 & -6.30 & -0.2766 & -24.16 \\
\hline Rice & -0.2873 & -24.97 & -0.0986 & $-9.39^{(2)}$ \\
\hline Other agricultural activities ${ }^{(4)}$ & -0.1291 & -12.11 & 0.0253 & $2.56^{(2)}$ \\
\hline Non-registered employee & 0.0783 & 8.14 & -0.2711 & -23.75 \\
\hline Temporary employee & -0.0369 & $-3.62^{(2)}$ & -0.1103 & -10.44 \\
\hline Employee without specialization & -0.4130 & -33.84 & -0.2183 & -19.61 \\
\hline RMW/100 & 0.1350 & 14.45 & 0.1372 & 14.71 \\
\hline (RMW/100)*(Non-registered employee) & -0.1159 & -10.94 & - & - \\
\hline (RMW/100)*(Temporary employee) & -0.0241 & -2.38 & - & - \\
\hline$(\mathrm{RMW} / 100) *($ Employee without specialization) & 0.0639 & 6.60 & - & - \\
\hline$(\mathrm{RMW} / 100) *($ Coffee $)$ & - & - & -0.0239 & $-2.36^{(2)}$ \\
\hline$($ RMW/100)*(Manioc) & - & - & -0.0565 & -5.50 \\
\hline (RMW/100)*(Corn) & - & - & -0.0909 & -8.69 \\
\hline$($ RMW/100)*(Soya) & - & - & 0.0692 & 7.16 \\
\hline$($ RMW/100)*(Rice) & - & - & -0.0624 & -6.05 \\
\hline$(\mathrm{RMW} / 100) *($ Other agricultural activities) & - & - & -0.0510 & -4.97 \\
\hline$R^{2}$ & \multicolumn{2}{|c|}{52.56} & \multicolumn{2}{|c|}{52.43} \\
\hline$F$ test $^{(5)}$ & \multicolumn{2}{|c|}{$2,402.80$} & \multicolumn{2}{|c|}{$2,159.20$} \\
\hline Number of observations & \multicolumn{2}{|c|}{60,754} & \multicolumn{2}{|c|}{60,754} \\
\hline
\end{tabular}

(1) Percentage increase in earnings associated with 1 additional year of schooling, beyond 9 years completed, by calculating, for instance, $100[\exp (0.0206+0.0929)-1] \%=12.01 \%$.

(2) The coefficients do not statistically differ from zero at significance level of $5 \%$.

(3) Rural areas of the states of Rondonia, Acre, Amazonas, Roraima, Pará and Amapá are not included.

(4) Other crops, except sugarcane.

(5) The values of $F$ are statistically significant at the level of $1 \%$.

Note: The dependent variable is the logarithm of the earnings from the main occupation. 
centration of the area under cultivation and the of production in 19 crops, using data from the Agricultural Census of 1975 and of 1980, and show that the sugarcane culture is the most concentrated amongst all the crops analyzed. It should be noted, however, that concentration of production in the industrial sector is in general far higher than in agriculture. Beans, corn and manioc are crops that typically have a low concentration index in Brazil.

The most recent information about concentration in the sugarcane production in Brazil and in the state of São Paulo is in a paper by RAMOS (2008). Taking into account, moreover, the concentration of economic and political power in the hands of the sugar mill and big land owners, one could say that the sugarcane agribusiness reproduces the high inequality characteristic of the Brazilian economy. This does not mean, however, that the sector's expansion will increase the inequality of income distribution in Brazil.

One way of examining the sector's impact on the distribution of income in general is to consider the income of people employed in that sector as a share of the income of all households in the country.

Let us assume that the household income per capita $\left(y_{i}\right)$ of the $i$-th household is divided in $k$ components $\left(y_{h i}\right)$, as follows,

$$
y_{i}=\sum_{h=1}^{k} y_{h i}
$$

Be $G$ the Gini index of the distribution of the household income per capita, be $C_{h}$ the concentration ratio of the component $y_{h i}$ and be $\varphi_{h}$ the share of this component in total income. It can be demonstrated that the Gini is a weighted average of the concentration ratios, namely,

$$
G=\sum_{h=1}^{k} \varphi_{h} C_{h}
$$

It is reasonable to consider that a component contributes to the increase in inequality when its concentration ratio is greater than the Gini index.

Using data from PNAD 2006, it is possible to verify that in Brazil with 53.45 million households and a populstion of 182.34 million, the Gini index is 0.56 . Earnings from work by people occupied in the sugarcane agribusiness (sugarcane culture + sugar industry + ethanol industry) represent $0.63 \%$ of total income and their concentration ratio equals 0.291. Earnings from work in all other activities represent $75.2 \%$ of total income and their concentration ratio is 0.566 . These results indicate that a uniform increase in the income of people occupied in the Brazilian agribusiness would contribute to a reduction of income inequality in Brazil.

Still, using PNAD 2006 data, but considering only the State of São Paulo, the Gini index of the household income is 0.52 , for a population of 12.13 million households, corresponding to 39.43 million people. Earnings from work occupied in the sugarcane agribusiness represent $1.16 \%$ of the state's total income and their concentration ratio equals 0.339. Earnings from work from all other activities represents $77.77 \%$ of total income, and its concentration ratio is equal to 0.522 .

It is well known that PNAD questionnaires do not reflect very high incomes. This problem is to some extent attenuated when using data from the Demographic Census, which obtains information on people's income from a far larger sample than the annual PNAD. According to the 2000 Demographic Census, the State of São Paulo had 10.36 million households, with 36.61 million people. The Gini index of the per capita household income in the state is 0.593. Earnings from work of the people occupied in the sugarcane agribusiness represents $0.62 \%$ of total income and its concentration ratio equals 0.236 . Earnings from work in all other activities represent $80.11 \%$ of total income; and its concentration ratio is 0.594 .

All these results indicate that a small relative increase in the incomes of people occupied in the sugarcane agribusiness would contribute to a reduction in inequality of the distribution of per capita household incomes in the State of São Paulo.

Another way of analyzing the influence of the sector in the overall inequality of income distribution is to separate people occupied in the sector from the total employed population. Instead of a separation of household income into components, it is the population, the total number of persons, which is separated in groups. It is possible to ana- 
lyze, then, how the global inequality depends on the inequality among groups and on inequality within groups. For the latter component, a group or sector where inequality within the group is higher than global inequality obviously contributes to increase overall inequality.

A preliminary information about this question is presented in Table 7 with numbers for the Gini index of income in all activities for people occupied that had a positive value for such income. According to PNAD 2006 data, the total number of people with such characteristics in Brazil, comprising employees, self-employed workers and employers, is 78,394,000, with an average income of $\mathrm{R} \$ 883.00$ ( $\mathrm{R} \$$ of September 2006) and Gini index of 0.54. Table 7 shows that the Gini index in the sugarcane agribusiness is lower. The same is true if we separate only the people employed in sugarcane production or those in the sugar and ethanol industries. Moreover, Table 7 shows similar results when only the State of São Paulo is considered: the Gini index equals 0.513 for all employed, 0.439 for people in the whole sugarcane agribusiness sector, 0.357 for people occupied in the sugarcane agriculture, and 0.45 for the occupied in the industry of sugar and of ethanol.

Table 8 shows results obtained from the 2000 Demographic Census in the State of São Paulo.
Again, inequality in the sugarcane agribusiness is less than inequality for the total occupied people. What is curious is that, contradicting what is observed from PNAD data, when Census data are taken, inequality in the agricultural component of the sector is higher than inequality in the industrial component of the sector.

The fact that inequality within the sugarcane agribusiness is less than inequality among all occupied people, in Brazil as well as in the State of São Paulo, does not in itself prove that an expansion of the sector could not provoke any increase in inequality. It is also necessary to examine inequality among different sectors, the likely change in the composition of the labor force inside the sector, and the multiplier effects on other sectors. The fact is that the results we obtained do not support the idea that inequality within the sugarcane agribusiness is exceptionally high, or that expansion of the sector would contribute to an increase in the inequality of income distribution in Brazil or in the State of São Paulo.

\section{HARM AND DISPLACEMENT}

Even when growth of the sugarcane agribusiness in a region favors an increase in employment and average incomes, the possibility that a number

TABLE 7 Income distribution for people occupied ${ }^{(1)}$ in all activities, cf. PNAD data, in Brazil and the State of São Paulo, distinguishing the sugarcane agribusiness.

\begin{tabular}{|l|c|c|c|c|}
\hline \multicolumn{1}{|c|}{ Area } & \multicolumn{1}{c|}{ Sector } & N. of people (1000) & Average income (R\$) & Gini index \\
\hline Brazil & All & 78,394 & 883 & 0.540 \\
\hline Brazil & Sugarcane agribusiness & 805 & 722 & 0.448 \\
\hline Brazil & Sugarcane culture & 571 & 543 & 0.376 \\
\hline Brazil & Sugar+ethanol industry & 234 & 1,162 & 0.458 \\
\hline State of São Paulo & All & 18,734 & 1,139 & 0.513 \\
\hline State of São Paulo & Sugarcane agribusiness & 296 & 1,075 & 0.439 \\
\hline State of São Paulo & Sugarcane culture & 174 & 784 & 0.357 \\
\hline State of São Paulo & Sugar+ethanol industry & 122 & 1,488 & 0.450 \\
\hline
\end{tabular}

(1) Only people with positive income.

(2) $\mathrm{R} \$$ of September 2006. 
TABLE 8 Income distribution of people occupied(1) in all activities, cf. 2000 Demographic Census, in the State of São Paulo, distinguishing the sugarcane agribusiness.

\begin{tabular}{|l|c|c|c|}
\hline \multicolumn{1}{|c|}{ Sector } & N. of people (1000) & Average income (R\$) $^{(\mathbf{2})}$ & Gini index \\
\hline All & 14,818 & 891 & 0.564 \\
\hline Sugarcane agribusiness & 175 & 575 & 0.460 \\
\hline Sugarcane culture & 96 & 494 & 0.485 \\
\hline Sugar+ethanol industry & 79 & 673 & 0.399 \\
\hline
\end{tabular}

(1) Only people with positive income.

(2) In R\$ of July 2000 , when the legal minimum wage was $R \$ 151.00$.

Source: IBGE, 2000 Demographic Census.

of people could be negatively affected by such process is not trivial. It is possible to imagine sugarcane expanding into an area previously occupied by extensive cattle-raising. Production values per square kilometer or employment might rise, but the skillful cattle herder or the proud cowboy will not easily be transformed into a tractor driver. For him the process might be painful, forcing him to search for cattle-raising in other regions. It is necessary to implement measures in order to soften the transition, such as the much quoted retraining and relocation of the labor force.

More immediately evident is the difficulty of manual cane cutters. Given the need to adapt to the requirements of sustainable production growth, including environmental concerns and healthier working conditions, the activity of the cane cutter tends to disappear with the mechanization of the harvest. A large number of those employed in the sugarcane plantations of São Paulo are migrant workers from other states (see CARNEIRO et al., 2007; MENEZES, 2007). In this event, it might be necessary to implement new programs geared to the creation of employment opportunities in the regions of origin of these migrant workers (see MORAES et al., 2008).

\section{COMMENTS AND QUESTIONS}

Besides presenting data to improve the diagnosis of socioeconomic problems associated with the expansion of the sugarcane agribusiness, this paper aims at contributing to the elaboration of a research agenda in this area, in line with the themes and preliminary questions that follows.

a) The analysis of socioeconomic problems related to the expansion of the sugarcane agribusiness cannot be limited to the State of São Paulo. Suffice to recall that a large proportion of the cane cutters occupied in the state are migrant workers from the State of Minas Gerais and from the Northeast. It is obvious that the prospect of Brazil becoming a large ethanol supplier in world markets depends on national policies. This does not diminish the relevance of research and governmental programs that need to be put into action in the State of São Paulo.

b) More research is needed to establish with greater certainty the number of people occupied in the sector and their remuneration. The use of information from the Agricultural Census of 2006 will be very useful, but certainly cannot give a definitive answer to some of the questions.

c) How the concentration of production in the sector compares to other agricultural and industrial activities? Does the sector distinguish itself by some particular concentration of economic and political power?

d) Does the sugarcane agribusiness contribute to an increase in income inequality in Brazil?

e) Is the expansion of the sector likely to reduce or to reinforce inequality between regions in the country? 
f) Would it be appropriate to prohibit the pay by harvest contract for cutters in the manual sugarcane harvest?

g) Is there a need to maintain and improve the inspection to enforce labor legislation as in any other sector?

h) What are the potential impacts of the expansion of agribusiness on other economic sectors?

i) How will the competition for arable land and other inputs affect food production due to the sector's expansion?

j) Is it appropriate to establish land zoning, to allow or to prohibit sugarcane cultivation in certain areas? This question of course depends on agronomic considerations and socioeconomic concerns.

\section{REFERENCES}

BACCARIN, J. G.; ALVES, F. J. da; GOMES, L. F. C. Emprego e condições de trabalho dos canavieiros no centro-sul do Brasil, entre 1995 e 2007. In: XLVI Congresso Brasileiro de Economia e Sociologia Rural. Anais... Rio Branco: FAO, 2008. 21 p.

BALSADI, O. V. Mercado de trabalho assalariado na cultura da cana-de-açúcar no Brasil no período 1992-2004. Informações Econômicas, SP, v. 37, n. 2, p. 38-5, February 2007a.

BALSADI, O. V. Panorama dos salários na agricultura brasileira. Análise e Indicadores do Agronegócio, São Paulo: IEA, v. 2, n. 9, September 2007b.

BALSADI. O. V. O mercado de trabalho assalariado na agricultura brasileira e suas diferenciações regionais. São Paulo: Aderaldo \& Rothschild: Ordem dos Economistas do Brasil, 2008. 291p.

CAMARGO, A. M. M. P. et al. Dinâmica e tendência da expansão da cana-de-açúcar sobre as demais atividades agropecuárias, Estado de São Paulo, 2001-2006. Informações Econômicas. São Paulo, v. 38, n. 3, p. 47-66, March 2008.

CARNEIRO, M. S.; SOUSA, A.; MARINHO, K. Migração, estrutura agrária e redes sociais: uma análise do deslocamento de trabalhadores maranhenses rumo à lavoura da cana em São Paulo. In: NOVAES, J. R.; ALVES. F. (Org.). Migrantes: trabalho e trabalhadores no Complexo Agroindustrial Canavieiro (os heróis do agronegócio brasileiro). S. Carlos: Edufscar, 2007. p. 215-232. k) What kind of programs should be approved in order to help the transition process for those dislodged or affected by the expansion of sugarcane? How can such programs be carried into effectively?

1) As in any sector, enforcement of environmental protection laws is needed. But there are still specific questions that the sector needs to face e.g. sugarcane burning during the harvest. Would it be appropriate to phase out sugarcane burning sooner? How can the legal framework be improvement?

m) Can the expansion of the sugarcane agribusiness shows it will contribute to an increase in welfare for present and future generations?

CORRÊA, A. M. C. J.; HOFFMANN, R. Fatores condicionantes da desigualdade de rendimentos na agricultura paulista: 1984-90. Revista Brasileira de Economia. Rio de Janeiro, v. 4, n. 51, p. 471-487, Oct./Dec. 1997.

FREDO, C. E. Impactos no emprego. Trabalho apresentado no Workshop sobre "Impactos da evolução do setor sucroalcooleiro no Estado de São Paulo", Campinas, CATI, 16 May 2008.

GONÇALVES, J. S. Avanço da mecanização da colheita e da exclusão social na produção canavieira paulista nos anos 90. Cadernos de Ciência \& Tecnologia, Brasília, v. 16, n. 1, p. 67-86, Jan./Apr. 1999.

HOFFMANN, R. Segurança alimentar e produção de etanol no Brasil. Segurança Alimentar e Nutricional, Campinas: NEPA - UNICAMP, v. 13, n. 2, p. 1-5, 2006.

HOFFMANN, R.; OLIVEIRA, F. C. R. de. Evolução da remuneração das pessoas empregadas na cana-de-açúcar e em outras lavouras, no Brasil e em São Paulo. In: XLVI Congresso Brasileiro de Economia e Sociologia Rural. Anais... Rio Branco: FAO, 2008a. 19 p.

HOFFMANN, R. ; OLIVEIRA, F. C. R. de. Remuneração e características das pessoas ocupadas na agroindústria canavieira no Brasil, de 2002 a 2006. In: XLVI Congresso Brasileiro de Economia e Sociologia Rural. Anais... Rio Branco: FAO, 2008b. 19 p.

HOFFMANN, R. O rendimento das pessoas ocupadas na agroindústria canavieira no Brasil. In: MACEDO, I. C. (Org.). A energia da cana-de-açúcar: doze estudos sobre a agroindústria da cana-de-açúcar no Brasil 
e a sua sustentabilidade. 2. ed. São Paulo, UNICA, 2007, seção 12.5, p. 220-225.

HOFFMANN, R.; NEY, M. G. Desigualdade, escolaridade e rendimentos na agricultura, indústria e serviços, de 1992 a 2002. Economia e Sociedade. Campinas, v. 13, n. 2, p. 51-79, Jul./Dec. 2004.

HOFFMANN, R.; SILVA, L. A. C. Contribuição ao estudo da concentração da produção agropecuária no Brasil em 1975 e 1980. Revista de Economia Rural 24 (2):145-159, 1986.

IBGE (2007). Pesquisa Nacional por Amostra por Domicílios 2006, v. 27, Brasil, Rio de Janeiro, IBGE.

IEA - Informações Estatísticas da Agricultura - Anuário IEA, vários anos. São Paulo, Instituto de Economia Agrícola.

MACEDO, I. C. (Org.). A energia da cana-de-açúcar: doze estudos sobre a agroindústria da cana-deaçúcar no Brasil e a sua sustentabilidade, 2. ed. São Paulo: UNICA, 2007.

MENEZES, M. A. de; SATURNINO, M. As migrações sazonais do sertão paraibano para as usinas canavieiras de São Paulo: In: NOVAES, J. R.; ALVES, F. (Org.). Migrantes: trabalho e trabalhadores no complexo agroindustrial canavieiro (os heróis do agronegócio brasileiro). São Carlos: Edufscar, 2007. p. 233-256.

MORAES, M. A. F. D de. Indicadores do mercado de trabalho do sistema agroindustrial da cana-de-açúcar do Brasil no período 1992-2005. Estudos Econômicos, v. 37, n. 4, p. 875-902, Oct./Dec. de 2007a.

MORAES, M. A. F. D de. Número e qualidade dos empregos na agroindústria da cana-de-açúcar. In: MACEDO, I. C. (Org.). A energia da cana-de-açúcar: doze estudos sobre a agroindústria da cana-de-açúcar no Brasil e a sua sustentabilidade. 2. ed. São Paulo, UNICA, 2007b, seção 12.4, p. 214-220.

MORAES, M. A. F. D. de. O mercado de trabalho da agroindústria canavieira: desafios e oportunidades. Economia Aplicada, São Paulo, v. 11, n. 4, p. 605-619, Oct./ Dec. 2007c.

MORAES, M. A. F. D. de; FIGUEIREDO, M. G. de; OLIVEIRA, F. C. R. de; DETOMINI, E. R. Migração espontânea de trabalhadores no setor sucroalcooleiro. In: XLVI Congresso Brasileiro de Economia e Sociologia Rural. Anais... Rio Branco: FAO, 2008. 19 p.

NOGUEIRA, E. A.; BAPTISTELLA, C. da S.L.; VICENTE, M. C. M.; CARMO, M. S.; VIEIRA, L. C. Estatísticas de salários agrícolas no Estado de São Paulo. São Paulo: IEA, 1992. 100 p.

OLIVEIRA, A. M. S. As inovações tecnológicas e as novas formas de gestão e controle do capital sobre o trabalho. Revista Pegada Eletrônica, Presidente Prudente, v. 3, n. 1, out. 2002. Disponível em: <http://www.prudente. unesp.br/ceget/pegada.htm>. Accessed 23 July 2008.

OLIVEIRA. F. C. R. de. Ocupação, emprego e remuneração na cana-de-açúcar e em outras atividades agropecuárias no Brasil, de 1992 a 2007. 167 p. Dissertação (Mestrado em Economia Aplicada) - Escola Superior de Agricultura "Luiz de Queiroz", Universidade de São Paulo, Piracicaba, 2009.

RAMOS, P. A Relação Terra-Trabalho na História Recente (1930-2005) da Lavoura Canavieira do Brasil. In: VII Congresso Brasileiro de História Econômica. Anais... Sergipe: ABPHE, Sept. 2007.

RAMOS, P. Os impactos da expansão da lavoura canavieira na estrutura fundiária e as manifestações de sua concentração no Brasil. Trabalho apresentado no Workshop sobre "Impactos da evolução do setor sucroalcooleiro no Estado de São Paulo”, Campinas, CATI, 16 May 2008. SÃO PAULO, Estado de. Lei Estadual n. 11.241, de 19 de setembro de 2002. Dispõe sobre a eliminação gradativa da queima da palha da cana-de-açúcar e dá providências correlatas. Disponível em://http://www.cetesb.sp.gov.br/ licenciamentoo/legislacao/estadual/leis/2002. Acessed: 25 April 2008.

SÃO PAULO (Estado). Protocolo Agro-ambiental do Setor Sucroalcooleiro Paulista, de 4 de junho de 2007. Disponível em: <http://homologa.ambiente.sp.gov.br/ etanolverde/protocolo.asp>. Acessed 25 April 2008.

SZMRECSÁNYI, T. O planejamento da agroindústria canavieira do Brasil (1930-1975). São Paulo, HUCITEC - UNICAMP, 1979.

VEIGA FILHO, A. A.; SANTOS, Z. A. P. de S.; VEIGA, J. E. R.; OTANI, M. N.; YOSHII, R.J. Análise da mecanização do corte da cana-de-açúcar no estado de são Paulo. Informações Econômicas. São Paulo, v. 24, n. 10, Oct. 1994.

VIEIRA JUNIOR, P. A.; VIEIRA, A. C. P.; BUAINAIN, A. M.; LIMA, F.; SILVEIRA, J. M. F. J. Produção brasileira de cana-de-açúcar e deslocamento da fronteira agrícola no Estado do Mato Grosso. Informações Econômicas. São Paulo, v. 38, n. 4, p. 58-77, Apr. 2008. 
